\title{
To a Question of New Strategies of Ethnocultural Policy of Modern States
}

\author{
Dr. Helen Karsanova \\ Odintsovo Institute for the Humanities, Moscow, Russia \\ E-mail: e_karsanova@mail.ru
}

\section{Doi:10.5901/mjss.2013.v4n9p23}

\begin{abstract}
Today, when practically everywhere the structure of modern national states loses the uniformity, and explosive forces of multiculturalism generate very serious political and sociocultural problems, the question foregrounds, whether it is possible to find an adequate equivalent to reach a unification of the civil and ethnic nation. This article is an attempt to answer this question. The author undertook comparative research of the German, French and British models of multiculturalism and came to a conclusion that in Europe it is possible to speak about multiculturalism with a considerable bit of convention. The source of modern interethnic problems is rather not in cultural, but in the social and economic spheres without solving which the preservation of the multicultural society can be put under doubts. For the Russian Federation such comparison is very important as multicultural strategy, having become part of ideological baggage of liberal reforming of the Russian society, is as well vulnerable for criticism.
\end{abstract}

Keywords: multiculturalism; ethnocultural pluralism; ethnic minority; international relations; all-civil identity;

Multiculturalism, being a system of the representations, focused on recognition of the collective rights behind ethnocultural groups, preservation and development of ethnic and cultural diversity in the country and in the world, became a global challenge for "cultural hegemony" of modern national state (Gramshi).

At the end of 2010 - beginning of 2011 political leaders of Germany, Great Britain and France made statements for "a multiculturalism failure" that became a significant event in socio-political and ethnocultural life of Western Europe.

Certainly, leaders of three leading countries of the European Union didn't put into question the need of harmonious coexistence of representatives of various ethnocultures and religions in one state. They focused attention of the world community on incorrectly chosen principle of the organization of interaction of various ethnoconfessional and cultural communities living in the territory of the national state.

While tolerant Europe shows gradual withdrawal from pluralism, and the critic of ideas of multiculturalism has become the settled political tendency, in certain countries including Russia, the multiculturalism concept still remains an integral part of carried-out liberal reforms. It also explains the increased interest in a multiculturalism problem, and the search for new, adequate strategy of ethnocultural policy still remains an actual task for many modern states.

The term "multiculturalism" quite often designates an ethnocultural, confessional and ethnolinguistic diversity of the population of the country. Besides, there is a mixture of different levels of understanding of this term:

- as real situation in society;

- as politicians and management strategies;

- as theoretical construction and scientific concept (Orlova, 2011).

It is more acceptable, from the point of view of our research, to interpret the concept of "multiculturalism" as the policy of the state which is focused on guaranteed recognition of ethnic pluralism, the assertion of standards of social justice of each representative of national culture, and also theoretical, political and ideological justification of such policy.

Thus, the basic principles of multiculturalism policy are:

- the recognition of ethnic and cultural pluralism as the main characteristic of civil society by the state;

- the assistance in socialization of marginal cultural groups;

- the assertion of standards of social justice of each representative of the national culture (equal opportunities for all citizens of the country);

- the support of reproduction and development of ethnic cultures.

Multiculturalism discourse, at least declaratively, received political and ideological appeal in Europe in the 1980th the beginning of the 1990th. The Schengen Agreements of 1985 and 1990 became the basis for coordination of the conditions of short-term visas issue for the countries, and the Amsterdam Agreement (of 1997 clause 73K) 
predetermined for the European Council the main directions of immigration policy in questions of lawful and illegal entrance and stay. Members of the EC have the right to independently define methods of formation of civil society and forms of interethnic interaction in their countries. That is, the principles of the organization of interethnic interaction, the understanding and the content of the attitude towards multiculturalism in the European countries are various. The "probation" by multiculturalism happened and is still happening in essentially different countries by their economic, sociopolitical, ethnocultural, ethnodemographic characteristics, where it is part of the state policy and is secured by law (Canada, Australia), or where its main principles are taken into account when the strategy of internal political development of the state is worked out (Great Britain).

In other words, it is relevant to speak about the German, French and British models of multiculturalism which need serious examination. The matter is that the attitude to multicultural policy widely discussed in the 1980-1990th, regarding the European countries had more declarative character, than a real state policy. The concrete measures corresponding to ideas of multiculturalism were undertaken only in the Netherlands, Sweden and partially in Great Britain.

In 1957 the term "multiculturalism" characterized domestic policy of Switzerland. In the 1970th when the Canadian government admitted the Official Act of multiculturalism, these ideas gained official recognition in other European countries. In fact, the strategy of the Canadian approach grew from a number of political experiments undertaken in 1960th and 1970th, and, most likely, was used not only to facilitate the integration of immigrants from "the third world" and Europe in the Canadian society. It is possible to agree with the opinion that "multiculturalism was meant to be the program of nation construction" and was put forward as a counterbalance to Quebec separatism (Landi, 2013). The idea consisted in blocking Quebec separatism by recognition of broader ethnic and cultural diversity.

In 1972 in the structure of the Secretary of State Department was created the Directory of the multiculturalism, and a new state strategy was legislatively fixed in 1982 in the Declaration of the Rights and Freedom and in the Act of multiculturalism in 1988. The Canadian model of multiculturalism had to be a prototype for building of new national consciousness of citizens.

The distinctive feature of the Canadian multiculturalism has become the coexistence of two opposite ethnic communities (French and British), which gave an opportunity to choose the type of socialization, based on distinctions of culture, and excluded possibility of rigid assimilation. The main reference point of the Canadian model of multiculturalism is the protection and the investment with the special rights of collective individuals - representatives of other ethnocultures and ethnic minorities. Members of ethnic communities of Canada have a real opportunity to use "native" languages and a number of the rights from the Charter of Rights and Freedoms. Similar strategy, based on the recognition by the state of ethnic and cultural pluralism as the main characteristic of civil society, apparently, proves its efficiency.

Thus, in Canada it was succeeded to create what Ms. Teylor called "ideology of multiculturalism", i.e. "the idea that our society is capable to welcome and integrate distinctions"(Teylor, 2010).

The successful realization of the multiculturalism policy was shown also by Australia, where a number of laws focused on providing equal opportunities for polyethnic population of the country were passed. Multiculturalism in Australia was institutionalized in 1979 when under the initiative of the government the Australian Institute of cultural diversity was created. The Direction of multiculturalism problems was founded in 1987 (since 1996 it became part of Department of immigration), the National advisory board of multiculturalism, the leading aim of which was to develop main directions of the state ethnocultural policy was created in 1987. The government encouraged the establishment of different associations and the councils, and it was aimed at the development of various ethnic cultures. The main feature of the Australian model of multiculturalism is the state and individual responsibility for creating optimum conditions for representatives of non-identical ethnocultures and faiths. Authority concessions in favor of ethnic minority, in fact, changed the essence of adaptation processes: the members of national diasporas found it possible not to take into account requirements of the new environment. As a result the Australian society instead of international harmony received a cross-cultural distancing - voluntary isolation of representatives of ethnocultural groups, i.e."a segregation vice versa" (Tiryakian, 2003).

The difference between the Canadian and the Australian models of multiculturalism consists, first of all, in the fact that in Canada the essence of political programs was reduced to preservation and encouragement of ethnolinguistic communities, and in Australia it was focused on the recognition of the right to cultural identity and social integration for each individual.

Ideas of pluralism were as well fulfilled in the United Kingdom. In Great Britain multiculturalism was never proclaimed the official doctrine, and special measures for the support of ethnocultural minorities weren't carried out. And though in Great Britain ethnic minorities never had a lot of collective rights, they were always considered as full members 
of multicultural society. Here the protection of ethnic minority ("racial minority") is represented, first of all, in legal support which in practice is expressed that this or that representative of ethnic minority can go to court with an application of violation of his rights not as the individual but as the representative of ethnocultural minority.

The events of August, 2011 in immigrant quarters of London and some other English cities (Liverpool, Manchester, Bristol), bloody massacre in south London on May 22, 2013 provide us with a reason to assume that weak points of the British multicultural policy were considerable, and that becomes more and more obvious.

Today intolerance to any dissent replaces multiculturalism. Only $8 \%$ of the population of Great Britain support a state policy of ethnic and religious minority that certainly testifies the crisis of the British model of multiculturalism (Kondratieva, 2011).

The assimilative policy of France, which is forbidding group privileges and proclaims equality of all people, became an alternative to the Brithish policy of pluralism. Despite the "mosaic" of the society France never positioned itself as the multinational state, and putting in practice all the principles of multiculturalism conflicted with the French understanding of "state nation" that eventually led to ethnopolitical conflicts in suburbs of Paris in the fall of 2005. Since 1990's in France charges against the dictatorial policy of the central government are growing from the regions, including the ethnocultural area. Probably, these events and processes became the reason of reconsideration by the French state policy of the ethnocultural diversity of the population.

Analyzing the domestic policy of France of the 1990's concerning ethnocultural distinctions, A.Hargrivs characterizes the problem, which the French government had, as a forcedly made choice between the policy of pluralism and the policy of exclusion. Having chosen the golden mean, the French policy is aimed to accept "cultural distinctions provided that the minorities should limit within dominating cultural norms" (Hargrivs, 1995). The republican principle of France says: all citizens of France are French people.

The multiculturalism model in Germany is based rather on the ethnic principles, than on the political. In Germany Turkish migrants for a long time weren't allowed to get nationality in the third generation and become part of the German society. Nowadays the existence of national schools, studying in Turkish, accommodation in national enclaves not only limit the need for learning Germans, but also block the possibility of getting higher in the society and being part of it. In practice such "multicultural" measures paved led to the emergence of the ethnocultural "parallel society" in social structure, provoked its resistant ethnocultural isolationism, and the host country received possible ethnopolitical instability and threat of the national security. It can be proclaimed that the policy of multiculturalism, in this case, was considered to solve the problem of mass labor immigration and was more focused on segregation, than on integration.

Thus, declarative multiculturalism itself creates conditions for existence of "parallel societies", isolates not only national minorities, but also the majority, interfering with the perception of national minorities. According to Ms.Teylor's remark "it is possible to integrate newcomers and to fight against discrimination only if society of the host country is convinced that the inflow of immigrants is the benefit and if the population welcomes bigger cultural diversity, as it considers that it promotes dynamic development and disclosure of creative potential"(Teylor, 2010).

Analyzing trends of modern ethnocultural policy development in some European countries allows us to consider the dynamics undergoing ethnopolitical and sociocultural processes, in some cases as a solution to actual economic tasks and labor migration, in others - as a search for optimum ways of artificial creation of united multicultural space.

The conducted research allows to conclude that the declaration of the principles of multiculturalism doesn't give a guarantee of achievement of interethnic tolerance, on the contrary, its functional application, as a certain technique, is obviously unpromising right where the target state policy is realized. The establishment in the borders of one state of various cultural institutes separately for ethnic minorities and separately for the population not only doesn't solve a problem, but also provokes the increase in a cross-cultural distance. Resistant psychological estrangement of immigrants, their low political, social and economic status is indisputable confirmation of that.

Multicultural society only in that case can be kept unified if it is capable to combine ethnocultural distinctions and equality of inicial opportunities for all citizens of the country. Respectively no declarations, target programs and governmental measures will bring desirable result if issues of economic, social and structural property aren't solved.

The incorporation of the inoetnichny population in social institutes is possible by its active inclusion in social reproduction of society which is understood as the reproduction of the person and social communities in all variety of their social qualities, in unity with material preconditions and social conditions of their existence, and also by formation of optimum conditions for division of labor. Structural differentiation, promoting modification of the acquired values will decline ethnic groups to integration into the accepting society. In the long term structural transformations in an ethnic group, and as a result, a unification of the civil and ethnic nation can become a consequence of such form of ethnocultural interaction. On the basis of such interpretation, according to Ms.Habermas's remark, "- "the constitutional 
nationalism" can take a place of initial nationalism (Habermas, 2008).

Modern Russia has to solve the same problems which the European countries faced at different times: integration and consolidation of multiethnic society, formation of ideas of all-civil identity, uncontrollable migration, etc. Specifics of the Russian multiculturalism consists in the necessity of harmonization of the interethnic relations between citizens of one, as the growth of ethnophobia is directed, in first place, to the representatives of Caucasus people, who are citizens of the Russian Federation. Therefore functional application of this or that foreign experience of multiculturalism as certain technique in Russia is doomed to failure.

The Russian legislation, as in some foreign countries, doesn't operate with such concepts as "national" or "ethnic minority", they are regarded as synonyms, but according to international law, Russia fulfils the policy of preservation and development of ethnolinguistic and confessional identity of ethnocultural communities. The order and organizational forms of interests of cultural and language groups are mainly defined by the system of the federal structure developed in Russia.

According to the conventional principles and norms of international law ratified by international legal documents and acts, including The Framework Convention for the Protection of National Minorities (FCNM), and also being guided by the Constitution of the Russian Federation, the Russian state follows the principles of tolerance and the international consent that found reflection in the country legislation. In general, in our country a rather stable legal base providing protection of the ethnocultural rights of people of the Russian Federation is created. Nevertheless multicultural strategy of Russia has a number of disadvantages from the point of view of ensuring human rights. The matter is that the ethnic rights of ethnic minorities are completely provided in national subjects of federation, but have no appropriate protection out of their borders. At the same time, protection and ensuring the rights of not title people, including, Russians in the national republics in practice is under authority of local authorities and it deserves a lot of criticism.

Most likely there is a great need for institutional changes which would be focused not on mechanisms of functioning of socio-political system, but on the needs of individuals to which this system serves. The main goal of these changes should be the observance of human rights, which "have to precede and lie in the basis of modes of guaranteeing the cultural rights, and not the opposite" (Sokolovski,. In this case it is a question of developing individualized (or personalized) multiculturalism.

Multiculturalism in Russia can become reality not only on condition of recognition of ethnocultural diversity and the rights of ethnic minorities, but mainly on condition of cultivating national values, providing and protecting of the rights not only ethnos, but as well citizens of the country.

However, successful realization of the principles of multiculturalism as a way of maintaining unified the elaborated society is possible only in democratic society that assumes existence of the developed associated society. Therefore the efficiency of multiculturalism, as a method of achieving interethnic tolerance in modern states without stable democratic institutes, can be put under question.

At the same time, we believe that movement to multicultural integration is inevitable. As domestic and foreign experience shows, formation and development of the multiculturalism, as a continuous practice of compromises and tolerance, is a long and inconsistent process. However, difficulties and problems in the sphere of the interethnic relations don't mean potential impossibility of realization of these principles.

\section{References}

Gramshi A. Prison Nitebooks 1929-1935 [Online] Available: http://www.marxists.org/archive/gramsci/

Habermas J. (2008) The implication of the other. Sketch-boom of the political theory. Saint-Petersburg, p.216.

Hargreaves A. (1995). Immigration, "race" and ethnicity in contemporary France. London.

Kondratieva, Tamara, (2011), [Online] Available: http://www.perspektivy.info/srez/val/velikobritanija_v_lovushke_multikulturalizma_ 2011-10-07.htm

Landi, Cravier. (2013). [Online] Available: http://www.slate.fr/tribune/72049/canada-multiculturalisme-europe

Orlova, Irina, (2011), Africa colonizes Europe. [Online] Available: http://www.moskvam.ru/publications/read/?publication=336 (December, 2, 2011).

Sokolovsky S.V. To a criticism of the multiculturalism policy. [Online] Available: http://old.heritage-institute.ru/images/6/6d/EM14_p4760.pdf

Teylor, Ch. (2010). Speech at the International Political Forum in Yarislavl (September, 10, 2010). [Online] Available: http://2010.gpfyaroslavl.ru/viewpoint/CHarl-z-Tejlor-Zaschischaya-mul-tikul-turalizm.

Tiryakian E. (2003). Assessing Multiculturalism Theoretically: E Pluribus Unum, Sic et Non / Multiculturalism and Political Integration in Modern Nation-States. International Journal on Multicultural Societies (IJMS) Vol. 5, No. 1, p. 21. 